* Doutor em Direito na Universidade de Camerino, Itália. Professor Titular de Direito Civil da Faculdade de Direito da Universidade do Estado do Rio de Janeiro (UERJ). Advogado. E-mail: fav@tepedino. adv.br.

** Mestrando em Direito Civil pela Universidade do Estado do Rio de Janeiro (UERJ). Advogado. E-mail: franciscoviegas@icloud.com.

\section{NOTAS SObRe O Termo INICIAL DOS \\ Juros de Mora e o Artigo 407 do Código Civil}

\author{
Notes on the Default Interest's \\ INITIAL TERM AND THE BRAZILIAN CIVIL \\ Code's ARTICLE 407
}

Gustavo Tepedino*
Francisco Viégas*

Como citar: TEPEDINO, Gustavo; VIÉGAS, Francisco. Notas sobre o termo inicial dos juros de mora e o artigo 407 do Código Civil. Scientia Iuris, Londrina, v. 21, n. 1, p.55-86, mar. 2017. DOI: $10.5433 / 2178-8189.2017 \mathrm{v} 21 \mathrm{n} 1 \mathrm{p} 55$. ISSN: $2178-8189$.

Resumo: A definição do termo inicial dos juros de mora exige a adequada compreensão de sua função, tal seja, a de indenizar a vítima que fora indevidamente privada do capital que the era devido como decorrência da violação de dever obrigacional ou legal. Assumindo como premissa esta função, deve ser superada a dificuldade em se admitir a fluência de juros relacionados à obrigação que, resultando do inadimplemento, não possui objeto previamente determinado. Contabilizar os juros somente após a fixação do valor principal devido, por meio da leitura isolada do art. 407 do Código Civil, afigura-se incompatível com a função 
dos juros moratórios no ordenamento jurídico brasileiro, bem como revela contrariedade à ratio do dispositivo mencionado, analisado no artigo sob perspectiva histórico-sistemática.

Palavras-chave: Inadimplemento. Juros de mora. Termo inicial. Liquidez.

Abstract: Understanding the definition of the default interest's initial term requires a proper understanding of its objective, which is to indemnify the party who did not receive compensation for the other party's breach of contract. Furthermore, the existence of default interests in contractual obligations that have undetermined objects should be of no debate. Most importantly, those that actively calculate interests based on the eventual fixation of the principal amount with a mere interpretation of the article 407 of the Brazilian Civil Code are not noticing the incompatibility of default interests in the Brazilian legal system. Even more, it contradicts the legal reasoning of this mechanism, whose origin indicates an absence of relation to the default interest's initial term.

Keywords: Default. Default interest. Initial term. Liquidity. 


\section{INTRODUÇÃO}

A sistematização de questões fundamentais do direito civil revelase, por vezes, desafiadora, a exigir do intérprete esforço na harmonização das fontes normativas, cuja compreensão não prescinde da análise funcional do objeto de estudo controvertido. Acentua-se a dificuldade diante de figuras presentes nos mais variados sistemas, suscitando, em razão da diversidade de culturas jurídicas, pré-compreensões ancoradas em conceitos falsamente equivalentes (algo como, na sematologia, os falsos cognatos). Tal fenômeno tem ocorrido na definição do termo inicial da contagem dos juros de mora. Segundo conceituada doutrina, "[...] é a magna questão deste instituto" (CARVALHO DE MENDONÇA, 1911, p. 487). ${ }^{1}$

Como se sabe, consistem os juros na prestação devida em razão da disponibilidade do capital alheio. ${ }^{2}$ Os juros de mora associam-se, em regra, à responsabilidade civil, na medida em que compõem a indenização devida pela privação do capital correspondente ao descumprimento de dever jurídico - legal ou convencional. ${ }^{3}$ A disciplina conferida aos juros de mora foi objeto de disputa sobretudo quanto às limitações impostas

1 A afirmação, do início do século passado, revela-se de grande atualidade.

2 "Os juros são, portanto, a prestação que enche o lugar ao que se tirou do patrimônio do credor" (PONTES DE MIRANDA, 2012b, p. 78). Ao propósito, José Xavier Carvalho de Mendonça (1960, p. 285), apoiado na lição de Lacerda de Almeida, ao distinguir os juros compensatórios e moratórios, afirma: "Em essência, ambos são compensatórios na ampla significação dêste termo". Estruturalmente, pode-se definir os juros como prestações acessórias que se integram à principal pelo decurso do tempo e que correspondem a uma alíquota/proporção dela. Sob o perfil funcional, os juros fundamentam-se na disponibilidade do capital alheio. Para uma análise dos aspectos estrutural e funcional na definição de juros, v. LIBERTINI, 1972, p. 95-97.

3 Controverte-se, contudo, acerca da natureza dos juros - se indenizatória ou punitiva -, tendo em vista a previsão de que são devidos "[...] ainda que não se alegue prejuízo" (art. 407 do Código Civil). Caio Mário da Silva Pereira (2014, p. 339-340) afirma que os juros moratórios “[...] significam uma penalidade imposta ao devedor em mora, daí sua denominação como juros moratórios". Álvaro Villaça Azevedo (2011, p. 203), na mesma direção, afirma que "[...] a vontade da lei, aqui, existe para punir o que se aproveita do alheio, como sanção inibidora dessa atividade ilícita”. Para Sérgio Campinho (2005, p. 196), nos juros moratórios "[...] destaca-se o objetivo de impor uma penalidade ao devedor em mora, de modo a coibir a inadimplência”. 


\section{à autonomia privada no contexto de combate à usura, notadamente} quanto à fixação da taxa aplicável. ${ }^{4}$ Em vista da vultosa influência que a regulamentação dos juros exerce sobre a economia, ${ }^{5}$ a previsão legal de taxa de juros deu origem a amplo debate doutrinário e jurisprudencial, culminando no entendimento, hoje consolidado no Superior Tribunal de Justiça, favorável à aplicação da Taxa SELIC. ${ }^{6}$

No que se refere ao termo inicial, questiona-se, de início, sua

4 Com efeito, ainda que a norma do art. 406 do Código Civil revista-se de caráter supletivo - isto é, aplica-se quando os juros moratórios não forem convencionados, ou o forem sem taxa estipulada -, o Decreto 22.626, de 7 de abril de 1933 (Lei de Usura) estabelece limite de taxa de juros, que não poderá exceder o dobro da taxa legal. Como esclarece Orlando Gomes (2016, p. 54), “[...] se as partes convencionarem taxa, terão de fazê-lo até o dobro da taxa legal, qual seja, aquela em vigor para a mora do pagamento de impostos devidos à Fazenda Nacional". Luiz Antonio Scavone Junior (2014, p. 250), em perspectiva semelhante, destaca que, "[...] ainda que o art. 406 do Código Civil de 2002 tenha definido apenas a taxa legal de juros moratórios, aplicável quando não houver convenção dessa espécie ou quanto a lei determinar sua aplicação, certo é que as partes não poderão convencionar livremente esses juros, ainda que a Emenda Constitucional 40/2003 tenha suprimido o limite de $12 \%$ ao ano do $\S 3^{\circ}$ do art. 192 da CF/1988”. E, mesmo nos casos em que é inaplicável a Lei de Usura, como no âmbito das taxas de juros e outros encargos cobrados nas operações realizadas por instituições, públicas ou privadas, que integram o sistema financeiro nacional (Súmula 596 do STF), a tendência jurisprudencial tem se direcionado no sentido de rever taxas consideradas abusivas nas relações de consumo. Ilustrativamente: STJ, REsp 1.061.530/RS, $2^{\mathrm{a}}$ S., Rel. Min. Nancy Andrighi, julg. 22.10.2008.

5 A regulamentação dos juros constitui uma das principais ferramentas na condução da política monetária. De outra parte, é consabida a “[...] milenar repulsa da Igreja Católica à cobrança do juro, que vislumbrava em tal expediente o 'pecaminoso' ato de se valer do 'status' de necessidade de outrem para auferir vantagem pecuniária. [...] tal aversão dos católicos à cobrança de juros nas pactuações creditícias só cedeu quando se passou a vislumbrar que tais operações não serviriam tão somente para suprir necessidades mínimas dos devedores, mas em muitos casos, para propiciar a inauguração ou alavancagem da atividade empresarial, geradora de riquezas, tributos e, sobretudo, empregos para terceiros" (FERRAZ, 2005, pp. 489-490). Percorrendo a história dos juros desde os "[...] primitivos albores da civilização [...]", v. CARVALHO DE MENDONÇA, 1911, pp. 77-81.

6 Dispôs o artigo 406 do Código Civil: "Quando os juros moratórios não forem convencionados, ou o forem sem taxa estipulada, ou quando provierem de determinação da lei, serão fixados segundo a taxa que estiver em vigor para a mora do pagamento de impostos devidos à Fazenda Nacional”. A Corte Especial do Superior Tribunal de Justiça deu provimento aos embargos de divergência opostos em face de acórdão da Terceira Turma para determinar que " [...] a taxa dos juros moratórios a que se refere o referido dispositivo (o art. 406 do Código Civil) é a taxa referencial do Sistema Especial de Liquidação e Custódia - SELIC, por ser ela a que incide como juros moratórios dos tributos federais (arts. 13 da Lei 9.065/95, 84 da Lei 8.981/95, 39, $\S 4^{\circ}$, da Lei $9.250 / 95,61, \S 3^{\circ}$, da Lei $9.430 / 96$ e 30 da Lei 10.522/02)" (STJ, EREsp 727.842/SP, Corte Especial, Rel. Min. Teori Albino Zavascki, julg. 8.9.2008). A questão, contudo, ainda gera divergências, mormente porque a taxa SELIC alberga, em sua composição, juros e correção monetária, o que, segundo o próprio STJ, geraria “[...] problema difícil de se contornar, quando, por exemplo, fossem fixadas condenações em que juros e correção monetária fluíssem de momentos distintos, o que não é difícil de ocorrer" (STJ, EDcl no REsp 1.025.298/RS, 2ª S., Rel. p/ Acórdão Min. Luis Felipe Salomão, julg. 28.11.2012). Em doutrina, vale mencionar, em perspectiva crítica à adoção da taxa SELIC no âmbito de aplicação do artigo 406 do Código Civil, os estudos de Sergio Campinho (2005) e Leonardo Mattietto (2003). 
definição nas obrigações ilíquidas. ${ }^{7}$ Há considerável dificuldade em se admitir a fluência de juros relacionados à obrigação cujo objeto não se encontra previamente determinado, como no caso do dano moral. $\mathrm{O}$ raciocínio pressupõe a injustiça de responsabilizar o devedor que não pode cumprir sua obrigação, por desconhecê-la. Somente poderiam ser contabilizados os juros, portanto, após a fixação do valor principal devido. A tese, contudo, não obstante o respeito que merecem seus fautores, ignora a ratio dos juros moratórios. De um lado, os juros de mora teriam por função, sob a ótica da responsabilidade civil, indenizar a vítima do descumprimento, privada, indevidamente, do capital de que poderia dispor. ${ }^{8}$ Tal perspectiva, se adotada, deve levar em conta a transformação por que passou a responsabilidade civil, transferindo-se sua preocupação central para a vítima do dano injusto. ${ }^{9}$ Diante da constatação de que a privação do capital representaria, per se, um dano, o ordenamento impõe o pagamento dos juros, os quais correm a partir do momento em que a vítima faria jus ao bem, independentemente, quanto a este aspecto, da reprovabilidade da conduta do civilmente responsável.

De outra parte, alude-se ao aspecto punitivo dos juros de mora, associado à vedação ao enriquecimento sem causa. Assume-se, como

7 A noção de liquidez era prevista no Código Civil de 1916, que, em seu art. 1.533, estabelecia: "Considerase líquida a obrigação certa, quanto à sua existência, e determinada, quanto ao seu objeto". J. M. de Carvalho Santos (1963, p. 348) afirmava, então, que "[...] líquida é a obrigação certa sobre a qual não pode haver dúvida an, quid, quale, quantum debeatur, ou sejam precisamente as obrigações determinadas pela respectiva espécie, qualidade e quantidade".

8 Arnoldo Wald (1959, p. 41) destaca, quanto à liquidação do valor devido por responsabilidade civil, que se deve atribuir ao ofensor (e não à vítima) os ônus decorrentes da privação do patrimônio: "[...] se a vítima não é completamente indenizada, sacrificamos um interesse individual a outro, provocando verdadeiro enriquecimento sem causa em favor do responsável pelo ato ilícito, que pagará uma quantia inferior ao atual valor do prejuízo. Ora, a distribuição da justiça e o interesse social exigem que haja uma reparação integral do dano, reintegrando-se a vítima na situação anterior ao ato ilícito".

9 Em conhecia passagem, alude-se a verdadeiro giro conceitual: (GOMES, 1989, p. 291-302). Poder-se-ia falar, mesmo, na "[...] passagem da responsabilidade civil ao direito de danos, mais focado na vítima e menos no causador ou na reprovação de sua conduta" (FACHIN, 2010, p. 19). Anderson Schreiber (2013, p. 161) observa que, "[...] hoje, o objetivo das cortes, na aplicação da responsabilidade civil, tem sido menos o de identificar um responsável que se vincule (pela sua culpa ou pela sua atividade) ao dano, e mais o de assegurar, por qualquer meio disponível, a integral reparação dos prejuízos sofridos pela vítima". 
premissa, que a disponibilidade do capital representa lucro, de modo que, se é alheio o capital, tal lucro deve ser revertido àquele que legitimamente deveria tê-lo auferido. ${ }^{10}$ Também sob esse ângulo, a conclusão não se altera, considerando que, se o devedor obteve vantagem a partir da indevida disponibilidade do capital alheio, ${ }^{11}$ os juros devem ser contados desde o momento em que se tornou indevida tal titularidade, termo inicial dos proveitos econômicos dela decorrentes. ${ }^{12}$

Há quem proponha, ainda, que os juros de mora tenham seu termo $a$ quo, em qualquer caso, na data da citação inicial. ${ }^{13}$ A solução, contudo, parece contrariar o arcabouço teórico sobre o qual se funda a figura dos juros moratórios, ignorando o sistema adotado pelo Código Civil. Atémse à literalidade de um único artigo para transformar sensivelmente o complexo de efeitos do inadimplemento, dele desvinculando a prestação de juros. ${ }^{14}$ Ao propósito, o CPC, em seu artigo 240, caput, parece atento

10 Como observa Carlos Nelson Konder (2005, p. 379), no enriquecimento sem causa, “[...] a reparação do dano sofrido, quando ocorre, é sempre indireta, pois o que se busca é remover a vantagem auferida por um para transferi-la a quem ela era de direito". Nessa direção, a ausência de causa que possibilitaria a ação de enriquecimento sem causa estaria relacionada à falta de "[...] título jurídico idôneo a justificar aquele enriquecimento" (KONDER, 2005, p. 390).

11 Lacerda de Almeida (1934, p. 356-357) afirma que foi Jeremy Bentham "[...] quem trouxe, pelo menos para effeitos juridicos, até as suas ultimas consequencias a theoria da rentabilidade do dinheiro. Se a terra dá renda, argumenta elle, se as casas dão aluguel e tantas outras cousas que frutificam em dinheiro com a periodicidade dos fructos naturaes e civis; por que razão o dinheiro não renderá tambem, abstracção feita de sua applicação, o dinheiro como dinheiro, por que razão não se lhe poderão perceber os fructos?".

$12 \mathrm{O}$ tema se insere na discussão mais ampla acerca do lucro de intervenção. Para o exame do estado atual da doutrina, com amplas referências bibliográficas, v. (TERRA, 2015, p. 445-458). v. também (LINS, 2016).

13 Assim sustenta Luiz Antonio Scavone Junior (2014, p. 543) em estudo aprofundado sobre o tema. Para o autor, “[...] no âmbito do Código Civil não há qualquer relação entre a mora do devedor e os juros moratórios, cujo termo inicial, nos termos da regra geral do art. 405, é sempre a data da citação inicial para a ação". Sendo assim, argumenta que, mesmo no caso de atos ilícitos, "[...] a mora é presumida a partir da prática do ato (responsabilidade extracontratual). Todavia, em razão da regra geral do art. 405 do Código Civil de 2002, os juros moratórios são contados a partir da citação" (SCAVONE JUNIOR, 2014, p. 415).

$14 \mathrm{O}$ apego à aparente clareza de uma única norma, propondo-se remodelação da inteira disciplina do inadimplemento, não se coaduna com a moderna concepção de segurança jurídica, a qual "[...] não se identifica com a clareza da regra abstrata senão com a argumentação coerente que deve fundamentar e motivar as decisões" (TEPEDINO, 2014, p. 8). Nessa direção, já se alertou para a necessidade de "[...] assunção pela doutrina de seu papel orientador e sistematizador, para que forneça aos juízes, para além das apostilhas impressas como cursos de direito, os fundamentos dogmáticos de suas decisões, com base em premissas teóricas sólidas e bem definidas" (TEPEDINO, 2014, p. 8). Nessa linha de raciocínio, o STJ já se manifestou, em sede de recurso repetitivo, sobre a intepretação do art. 405 do Código Civil, o qual 
à sistemática do Código Civil, ao estabelecer: "A citação válida, ainda quando ordenada por juízo incompetente, induz litispendência, torna litigiosa a coisa e constitui em mora o devedor, ressalvado o disposto nos arts. 397 e 398 da Lei no 10.406, de 10 de janeiro de 2002 (Código Civil)" (BRASIL, 2015, grifou-se). ${ }^{15}$

Torna-se indispensável, diante disso, o exame dos diversos termos iniciais previstos no Código Civil, de modo a identificar o termo aplicável a cada espécie de obrigação.

\section{A DEFINIÇÃO DO TERMO INICIAL DOS JUROS DE MORA}

O Código Civil prevê, em diferentes artigos, regras destinadas a regular o termo inicial dos juros de mora, a partir da distinção entre mora ex re e mora ex personae. Quando a mora é estabelecida em decorrência do próprio fato que a originou (ex re), sem necessidade de sua constituição pelo credor, contar-se-á o termo inicial: (i) desde a data do vencimento da obrigação contratual, conforme o artigo 397, caput, do Código Civil; (ii) desde a prática do ato ilícito extracontratual, ex vi do art. 398 do Código Civil, resultando aqui a mora de determinação legal (semper enim moram fur facere videtur). ${ }^{16}$

Quanto ao primeiro suporte fático, tem-se que, sendo possível extrair da própria obrigação elementos suficientes à identificação do

\footnotetext{
“[...] deve ser interpretado à luz do ordenamento jurídico, tendo aplicação residual para casos de mora ex persona, evidentemente se ainda não houve a prévia constituição em mora, por outra forma legalmente admitida" (STJ, REsp 1.556.834/SP, 2 ${ }^{\mathrm{a}}$ S., Rel. Min. Luis Felipe Salomão, julg. 22.6.2016).

15 Grifou-se. Nota-se, de fato, a preocupação do legislador quanto à questão, considerando que o artigo correspondente no CPC/1973 (art. 219, caput) não se pronunciava a respeito da disciplina do Código Civil, prevendo apenas que "A citação válida torna prevento o juízo, induz litispendência e faz litigiosa a coisa; e, ainda quando ordenada por juiz incompetente, constitui em mora o devedor e interrompe a prescrição".

16 "Nas obrigações provenientes de delito, a mora resulta de determinação da lei. Desde o momento em que o ato delituoso é cometido, os riscos da coisa devida correm por conta do devedor. Semper enim moram fur facere videtur" (BEVILAQUA, 1958, p. 95).
} 


\section{conteúdo da prestação ${ }^{17}$ e do prazo para seu cumprimento, ${ }^{18}$ os juros} fluirão desde o momento em que deveria ter sido cumprida a obrigação, ou seja, a partir do vencimento no prazo avençado. ${ }^{19}$

No âmbito extracontratual, por sua vez, a fluência dos juros moratórios assenta em previsão legal expressa. O art. 398 do Código Civil estabelece que "nas obrigações provenientes de ato ilícito, considera-se o devedor em mora, desde que o praticou" (BRASIL, 2002). A questão encontra-se contida, inclusive, na súmula 54 do Superior Tribunal de Justiça: "Os juros moratórios fluem a partir do evento danoso, em caso

17 Ao tratar da noção de obrigação positiva e líquida, Agostinho Alvim (1972, p. 117) esclarece que "[...] positiva é a obrigação de dar e de fazer [...]. O conceito de liquidez da obrigação pressupõe o de certeza [...]. É necessário que haja determinação da coisa fungível ou individuação da infungível. É líquida, p. ex., a obrigação de dar coisa certa, ou coisa incerta, quando haja determinação: tantos sacos de arroz de tal qualidade. De igual modo a alternativa, após a escolha [...]".

18 No que se refere ao prazo, não se vislumbra dificuldade na identificação do termo inicial quando se fixa o vencimento em data certa. Pode ser, contudo, que o termo estabelecido no contrato remeta a evento cuja data é incerta (assim, por exemplo, a morte de alguém). Outrossim, a obrigação pode estar submetida à condição suspensiva. Em ambas as hipóteses - de prazo incerto, porém determinável -, somente se poderá falar em mora do devedor e, consequentemente, de termo inicial dos juros de mora, se o credor comprovar que o devedor teve ciência do fato que possibilitou a determinação do prazo. A conclusão fundamenta-se no artigo 332 do Código Civil, que assim prevê: "As obrigações condicionais cumprem-se na data do implemento da condição, cabendo ao credor a prova de que deste teve ciência o devedor". Na doutrina, cf. (ALVIM, 1972, p. 121). Por outro lado, vale destacar a possibilidade de convenção acerca do termo inicial dos juros de mora em momento diverso da constituição em mora. Não obstante caminhem juntos - como causa e efeito - mora e juros moratórios, não parece haver óbice à fixação diferida do termo inicial dos juros. Se à autonomia privada reserva-se a possibilidade de excluir a incidência dos juros de mora, com maior razão poderá postergar o dies a quo. Ao propósito, Caio Mário da Silva Pereira (2014, p. 340 ), ao tratar dos juros moratórios no âmbito do contrato de mútuo, admite tal possibilidade: "[...] juros moratórios são aqueles aplicados quando há inadimplência do contratante com relação a uma ou todas as parcelas sobre o mútuo contraído. Eles significam uma penalidade imposta ao devedor em mora, daí sua denominação como juros moratórios. Incidem a partir do dia seguinte ao vencimento do mútuo ou o que for determinado em contrato".

19 Segundo o STJ, "[...] o caput do referido dispositivo legal, adotando o adágio dies interpellat pro homine (o termo interpela em lugar do credor), regula a mora ex re, em que o mero advento do tempo, sem o cumprimento da obrigação positiva e líquida, constitui o devedor automaticamente em mora. A razão de ser é óbvia: sendo o devedor sabedor da data em que deve ser adimplida a obrigação líquida, descabe advertência complementar por parte do credor. Deveras, havendo obrigação líquida e exigível a determinado termo - desde que não seja daquelas em que a própria lei afasta a constituição de mora automática -, o inadimplemento ocorre no vencimento" (STJ, REsp 1.270.983/SP, $4^{\mathrm{a}}$ T., Rel. Min. Luis Felipe Salomão, julg. 8.3.2016). Com efeito, “[...] a norma contida no art. 397 do CC/2002 abrange as obrigações de dar e de fazer cuja existência seja certa e que se encontrem determinadas em sua espécie, quantidade e qualidade. Em definitivo: a ratio do dispositivo associa-se à determinabilidade da prestação, quanto à sua existência e ao seu objeto, e à data do descumprimento, subordinada a termo certo, de molde a disparar imediatamente as consequências da mora" (TEPEDINO, 2012, p. 104). 
de responsabilidade extracontratual". ${ }^{20}$ Atento à orientação, o CPC, no já referido artigo 240, caput, prevê, dentre os efeitos da citação válida, a constituição em mora o devedor, "[...] ressalvado o disposto nos arts. 397 e 398 da Lei no 10.406, de 10 de janeiro de 2002 (Código Civil)" (BRASIL, 2015, grifou-se).

Quanto à mora nas obrigações negativas, releva notar o tratamento particular que lhe era reservado em doutrina. ${ }^{21} \mathrm{Na}$ vigência do Código de 1916, criticava-se a redação do artigo 961, o qual previa que, nas obrigações negativas, “[...] o devedor fica constituído em mora, desde o dia em que executar o ato de que se devia abster" (BRASIL, 1916). ${ }^{22}$ Superado o entendimento que negava a possibilidade de mora nas obrigações de não fazer, reservou-se, porém, pouca atenção à alteração na redação do artigo correspondente no Código vigente. Com efeito, no Código Civil de 2002, o artigo 390 se limita a preceituar que o inadimplemento da obrigação de não fazer se caracteriza pela prática da ação a cuja omissão o devedor se comprometera. O legislador não

20 Em recurso julgado sob a sistemática dos recursos repetitivos, o STJ já se manifestou no sentido de que "[...] a distinção importante para estabelecer o termo inicial da fluência dos juros é entre o ato ilícito relativo e o ato ilícito absoluto, ou seja, se se trata de responsabilidade contratual ou extracontratual [...]. Tratando-se de responsabilidade extracontratual - portanto ilícito absoluto, os juros incidirão a partir da data do evento danoso (artigo 962 do Código Civil de 1916)" (STJ, REsp 1.114.398/PR, 2ª S., Rel. Min. Sidnei Beneti, julg. 8.2.2012). Parece evidente, como destacou a Corte em outro julgado, que, na hipótese de condenação por ilícito extracontratual em que se estabelece prestação mensal em favor da vítima ou seus dependentes, os juros de mora respectivos correm a partir do vencimento de cada prestação, e não desde a prática do ato ilícito. Nesses casos, o STJ destaca: “[...] embora se trate de relação extracontratual, observa-se que a prestação não é de cunho singular, pagável uma única vez, mas é, na verdade, obrigação de trato sucessivo. Dessa forma, os juros moratórios que irão ser acrescidos ao valor da pensão não mais devem se iniciar a partir do ato ilícito - por não ser uma quantia singular -, tampouco da citação - por não ser ilíquida -, mas devem ser contabilizados a partir do vencimento de cada prestação, que ocorre mensalmente" (STJ, REsp 1.270.983/SP, 4a T., Rel. Min. Luis Felipe Salomão, julg. 8.3.2016).

21 Do magistério de Agostinho Alvim (1972) extrai-se a distinção pautada nas diversas modalidades das obrigações. O autor propõe divisão entre (i) obrigações a prazo; (ii) obrigações sem prazo; (iii) obrigações negativas; (iv) obrigações provenientes do delito.

22 Argumentava-se que não seria possível haver mora nas obrigações de não fazer, vez que, "[...] praticado o fato proibido, há obrigação de indenizar pelo inadimplemento absoluto e não pela mora" (ALVIM, 1972, p. 134). A tese, porém, não encontra amparo diante de obrigações negativas de caráter continuado. Como já observava Pontes de Miranda (2012a, p. 193), “[...] não é verdade que não haja mora de obrigações negativas [...]", já que havendo "[...] possibilidade de ser elidido o efeito da inexecução, o devedor pode ser admitido a purgar a mora e continuar abstendo-se". 
mais se propõe a estabelecer, portanto, o momento da constituição em mora, preferindo disciplinar a ação que caracteriza o inadimplemento da obrigação. ${ }^{23}$

A constituição em mora do devedor nas obrigações negativas torna-se, nessa medida, questão central para a apreensão das consequências do inadimplemento, sendo necessário analisar a partir de que momento se considera constituído em mora o devedor que, por sua atuação comissiva, é havido por inadimplente. O tema se apresenta como reflexo da orientação contemporânea que afasta a certeza apriorística de que não haveria interesse útil do credor em face do inadimplemento de obrigação negativa. Como consequência, percebe-se que também os requisitos que fundamentam a mora ex re nas obrigações positivas, ${ }^{24}$ notadamente a liquidez, podem - ao contrário do que se pressupunha não estar presentes nas obrigações negativas, sobretudo quando se está diante de ato jurídico complexo, no qual interagem diversas prestações, tornando-se nem sempre simples a tarefa de precisar se a atuação do devedor deu-se no tempo, lugar e forma devidos. Por isso que não se poderia identificar, em qualquer hipótese de inadimplemento de obrigação negativa, a mora ex re. Ganha relevância, nesse aspecto, a atuação da autonomia privada, tendo em vista que as partes podem, precavendose dos infortúnios advindos da indefinição quanto ao termo inicial dos efeitos da mora, convencionar a necessidade de interpelação para que se

$23 \mathrm{Na}$ linguagem do art. 390 do Código Civil, "Nas obrigações negativas o devedor é havido por inadimplente desde o dia em que executou o ato de que se devia abster".

24 Como destacou o Superior Tribunal de Justiça em questão afetada à sistemática dos recursos repetitivos, a "razão de ser" da mora ex re "[...] é singela: sendo o devedor sabedor da data em que deve ser adimplida a obrigação líquida - porque decorre do título -, descabe advertência complementar por parte do credor. Destarte, havendo obrigação líquida e exigível a determinado termo - desde que não seja daquelas em que a própria lei afasta a constituição de mora automática -, o inadimplemento ocorre no vencimento" (STJ, REsp 1.556.834/SP, 2 ${ }^{\mathrm{a}}$ S., Rel. Min. Luis Felipe Salomão, julg. 22.6.2016). Como se percebe, a configuração da mora, nessas hipóteses, está condicionada à certeza de que o ato constitui violação ao dever assumido, com margem restrita para o surgimento de perspectivas opostas acerca do fato que deflagra o inadimplemento. 
constitua em mora o devedor da obrigação negativa (mora ex personae).

De outra parte, o Código Civil, independentemente da vontade das partes, exige de forma expressa a interpelação para a constituição do devedor em mora nas hipóteses em que se discute o inadimplemento associado a fatos imputáveis ao devedor que, na perspectiva do credor, caracterizariam o inadimplemento relativo. Nestas hipóteses, contarse-ão os juros de mora: (i) a partir da interpelação do devedor para o cumprimento de dívida contratual exigível, como dispõe o artigo 397, parágrafo único, do Código Civil; (ii) desde a citação inicial, na forma do artigo 405 do Código Civil, segundo o qual "contam-se os juros de mora desde a citação inicial" (BRASIL, 2002).

Na hipótese em que não se promove a interpelação em momento anterior à ação judicial, apenas com a citação se constitui o devedor em mora. Entretanto, suponha-se que, naquele momento inicial em que se deflagra a jurisdição, não se tenha ainda - como ocorre em muitas controvérsias - o valor líquido da dívida, que somente será estabelecido e apurado ao final do processo, muitas vezes com ajuda de peritos, correspondendo ao valor da condenação. ${ }^{25}$

Nestes casos, aplica-se o art. 407 do Código Civil, que, na

25 O cenário gera controvérsias também na seara arbitral. No âmbito da ICC International Court of Arbitration, a questão vem comumente analisada à luz da CISG (United Nations Convention on Contracts for the International Sale of Goods). No ICC Case n. 16369 (2011), a sentença arbitral considerou que o termo inicial dos juros deveria ser o momento em que ocorrida a lesão, independentemente da predeterminação do montante devido: "According to Art. 78 CISG the Claimant is entitled to interest on the "price or any other sum that is in arrears ... without prejudice to any claim for damages recoverable under article 74 ' [...]. The question has been raised whether Art. 78 may be relied upon only from the point in time when the amount in arrears has been ascertained - be it by a court or tribunal be it by the parties themselves. Authors and courts draw an argument against applying the provision in cases of not-yet-liquidated sums from the wording 'sum that is (emphasis by the Tribunal) in arrears' or, clearer still, the (equally authentic) French version 'somme $d u e^{\prime}$. If the Tribunal adopted that view the Claimant would not be entitled to pre-award interest [...]. In the Tribunal's opinion, however, the preferable solution is that interest on claims for damages is recoverable from the time when the loss occurred, irrespective of whether or not the precise amount of the claim has already been determined [...]. The Claimant did suffer a loss and a claim for monetary compensation therefore arose at the point in time when the onward sale contract (the profitability of which is on record) could not be performed on. The fact that the precise entity of that claims item was in dispute and has only now been established does not change the position". 
esteira do art. 1.064 da codificação de 1916, autoriza a cobrança dos juros moratórios independentemente do pedido e da natureza da prestação, firme no princípio geral de que o acessório segue o principal.

\section{A ACESSORIEDADE DOS JUROS DE MORA}

Os juros de mora, por constituírem vicissitude própria do inadimplemento, são devidos independentemente da demonstração de prejuízo por parte do credor. Presume-se que a privação de prestação exigível gere prejuízo ao credor, por suprimir-lhe a disponibilidade patrimonial. Além disso, atribui vantagem patrimonial ao devedor inadimplente, a qual, por força do princípio de proibição ao enriquecimento sem causa (art. 884), ${ }^{26}$ deve ser convertida em benefício do credor. ${ }^{27}$

Tal a opção assentada pelo Código ao preceituar, em seu artigo 407:

Art. 407. Ainda que se não alegue prejuízo, é obrigado o devedor aos juros da mora que se contarão assim às dívidas em dinheiro, como às prestações de outra natureza, uma vez que lhes esteja fixado o valor pecuniário por sentença judicial, arbitramento, ou acordo entre as partes.

26 Dispõe o artigo 884 do Código Civil: "Aquele que, sem justa causa, se enriquecer à custa de outrem, será obrigado a restituir o indevidamente auferido, feita a atualização dos valores monetários". A respeito da relação entre os juros moratórios e a vedação ao enriquecimento sem causa, v. (TEPEDINO; SCHREIBER, 2008, p. 388).

27 J. M. de Carvalho Santos (1964, p. 269) observa que “[...] os juros moratórios são devidos sem que haja necessidade de o credor provar que teve qualquer prejuízo". Mario Libertini $(1972$, p. 102) esclarece que "[...] quando, per uma ragione qualsiasi, possa provarsi che il creditore non abbia subito in concreto alcun danno, gli interessi sono ugualmente dovuti, e allora essi devono essere giustificati in primo luogo come compenso del vantaggio che il debitore consegue attraverso l'utilizzazione (in senso positivo o anche solo negativo, nel senso di omissione del ricorso ad una diversa fonte di credito) protratta di una somma altrui”. Ludovico Barassi (1946, p. 1.230) sintetiza da seguinte forma a questão: “[...] il danaro non se ne sta di regola inoperoso, quindi non ocorre provare il danno". 
Do dispositivo extrai-se, ainda, que os juros de mora são devidos seja qual for a natureza da prestação: obrigações pecuniárias ou de qualquer outra espécie (MONTEIRO, 2007, p. 334). Desse modo, tem-se por devidos os juros de mora mesmo que nada convencionem as partes a seu respeito, ou, ainda, fora do âmbito negocial, quando provierem de determinação legal, como nas obrigações decorrentes de ato ilícito. Somente se vislumbra hipótese de não serem devidos os juros de mora quando as partes, no exercício de sua autonomia privada, ajustarem a exclusão de tal prestação - além, é claro, dos casos em que a própria lei determina sua não incidência. ${ }^{28}$

Como decorrência da sistemática de incidência dos juros de mora - que aderem à prestação principal, como visto, independentemente de previsão negocial -, também o pedido, tanto na ação judicial quanto no procedimento arbitral, não precisará mencionar, necessariamente, a parcela correspondente aos juros de mora. Posto que seja omisso o pedido neste aspecto, eventual condenação incluirá os juros, os quais são imanentes à parcela principal. ${ }^{29}$ Nessa direção, sendo consentida a digressão processual, a denominada regra de congruência da decisão judicial, extraída dos artigos 141 e 492 do Código de Processo Civil, ${ }^{30}$ não afasta o dever de que se analisem, além dos pedidos deduzidos, os ditos

28 Assim a lição de Luiz Antonio Scavone Junior (2014, p. 125): “[...] para que não sejam devidos, nada obstante a mora, mister se faz a vontade das partes estampada no contrato ou lei determinando sua não incidência, como, por exemplo, o art. 552 do Código Civil, que isenta o doador do pagamento de juros moratórios".

29 Vale ressaltar que a questão já era analisada pela doutrina clássica. Câmara Leal (1930, p. 245), ao examiná-la, assinalava: "Pôsto que o pedido tenha omittido coisas que se devam considerar immanentes ao seu objecto, ou delle inseparaveis, deverá o Juiz comprhendel-as no pedido e sobre ellas pronunciar-se tambem, sem que se possa, nesse caso, considerar exorbitante a sentença, ou ultra petita. É assim que, embora silenciados pelas partes, deve o Juiz em sua sentença: [...] b) incorporar ao capital os juros [...]".

30 "Art. 141. O juiz decidirá o mérito nos limites propostos pelas partes, sendo-lhe vedado conhecer de questões não suscitadas a cujo respeito a lei exige iniciativa da parte"; “Art. 492. É vedado ao juiz proferir decisão de natureza diversa da pedida, bem como condenar a parte em quantidade superior ou em objeto diverso do que lhe foi demandado. Parágrafo único. A decisão deve ser certa, ainda que resolva relação jurídica condicional”. 
implícitos. ${ }^{31}$ E o próprio CPC desincumbe-se da questão, estabelecendo expressamente em seu artigo $322, \S 1^{\circ}$, que: “compreendem-se no principal os juros legais, a correção monetária e as verbas de sucumbência, inclusive os honorários advocatícios" (BRASIL, 2015).

O tema tornou-se, inclusive, objeto de súmula do Supremo Tribunal Federal, ${ }^{32}$ e a jurisprudência se encontra consolidada no sentido de que os juros de mora integram os chamados pedidos implícitos, afirmando-se, inclusive, que "a alteração ou modificação de seu termo inicial não configura julgamento extra petita ou ultra petita", conforme Agravo Regimental no Recurso Especial 1.459.006/SC, da $2^{\mathrm{a}}$ Turma do Superior Tribunal de Justiça, Relator Ministro Mauro Campbell Marques, julgamento em 10.3.2016. ${ }^{33}$

\section{O ART. 407 DO CÓDIGO CIVIL: PROPOSTA DE INTERPRETAÇÃO HISTÓRICO-SISTEMÁTICA}

Conforme já aludido, verifica-se acentuado debate sobre a definição do termo inicial dos juros de mora em relação às obrigações ilíquidas, tendo sido esta questão - notadamente quanto à fixação do termo inicial dos juros de mora nas obrigações de compensação por dano moral - objeto de divergência entre os Ministros da Segunda Seção do Superior Tribunal de Justiça.

Em 2011, a Quarta Turma do STJ decidiu, por maioria, no

31 Por pedido implícito, entende-se "[...] aquele que, embora não explicitado no instrumento da postulação, compõe o objeto litigioso do processo (mérito) em razão de determinação legal. Mesmo que a parte não peça, deve o magistrado examiná-lo e decidi-lo" (DIDIER JR, 2015, p. 590).

32 Súmula 254 do STF: "Incluem-se os juros moratórios na liquidação, embora omisso o pedido inicial ou a condenação".

33 O STJ possui jurisprudência firme no sentido de que "[...] os juros moratórios são consectários lógicos e ex lege da condenação, devendo o julgador agir, nessa seara, até mesmo de ofício, nos termos do art. 293 do CPC e da Súmula n. 254/STF” (STJ, AgRg no AREsp 401.543/RJ, 4ª T., Rel. Min. Luis Felipe Salomão, julg. 24.3.2015). 
julgamento do REsp 903.258/RS, que, “em se tratando de indenização por dano moral, os juros moratórios devem fluir, assim como a correção monetária, a partir da data do julgamento em que foi arbitrado em definitivo o valor da indenização". Nos termos do voto da Ministra Relatora Maria Isabel Gallotti:

[...] como a indenização por dano moral (prejuízo, por definição, extrapatrimonial) só passa a ter expressão em dinheiro a partir da decisão judicial que a arbitrou, não há como incidir, antes desta data, juros de mora sobre quantia que ainda não fora estabelecida em juízo. Dessa forma, no caso de pagamento de indenização em dinheiro por dano moral puro, entendo que não há como considerar em mora o devedor, se ele não tinha como satisfazer obrigação pecuniária não fixada por sentença judicial, arbitramento, ou acordo entre as partes. Incide, na espécie, o art. 1.064 do Código Civil de 1916, segundo o qual os juros de mora serão contados 'assim às dívidas de dinheiro, como às prestações de outra natureza, desde que lhes seja fixado o valor pecuniário por sentença judicial, arbitramento, ou acordo entre as partes'. No mesmo sentido, o art. 407 do atual Código Civil. ${ }^{34}$

Ainda em 2011, a Segunda Seção do STJ apreciou, no julgamento do REsp 1.132.866/SP, a questão do termo inicial dos juros

34 Vale destacar, contudo, o voto vencido do Ministro Luis Felipe Salomão, que, na interpretação do art. 407 do Código Civil, afirmou que "[...] mesmo nas obrigações ilíquidas, os juros fluem sempre respeitado o marco legal relativo à constituição do devedor em mora, incidentes naquele valor a que chegou a sentença, o árbitro ou o acordo entre as partes". Merece menção, ainda, o fato de que foram opostos embargos de divergência em face do acórdão. No entanto, no julgamento do EREsp 903.258/ RS, debateu-se exclusivamente a questão na natureza - contratual ou extracontratual - da relação que originou o dano moral: "No regime do Código Civil de 1916, a responsabilidade do hospital pela má prestação de serviços tem natureza contratual” (STJ, EREsp 903.258/RS, Corte Especial, Rel. Min. Ari Pargendler, julg. 15.5.2013). O mesmo posicionamento quanto ao termo inicial dos juros de mora na data da condenação foi adotado em outros julgados da Quarta Turma. V., exemplificativamente (STJ, REsp 888.751/BA, 4 $4^{\mathrm{a}}$ T., Rel. Min. Raul Araújo, julg. 25.10.2011; STJ, REsp 1.201.340/DF, 4a T., Rel. Min. Maria Isabel Gallotti, julg. 3.11.2011). 
de mora nas obrigações de compensação por dano moral. A Relatora Ministra Maria Isabel Gallotti, invocando o acórdão da Quarta Turma, manteve o posicionamento quanto à incidência dos juros somente a partir do momento da condenação. Prevaleceu, contudo, a tese oposta, na linha do voto do Ministro Sidnei Beneti, Relator para Acórdão neste Recurso Especial. Conforme observou o eminente Ministro:

[...] os juros moratórios diferem, etiologicamente, da correção monetária, pois esta serve como mera atualização do valor fixado, de modo que seu curso deve dar-se a partir da data cujas bases monetárias, atuais ou passadas, tenham sido consideradas para arbitrar a indenização, ao passo que os juros de mora, no caso de indenização, de qualquer natureza, devem correr a partir da data do evento causador do dano. Não obstante a indenização por dano moral só passe a ter expressão condenatória em dinheiro a partir da decisão judicial que a arbitra, a mora que fundamenta a incidência dos juros existe desde o ato ilícito que desencadeou a condenação à reparação dos danos morais. ${ }^{35}$

Não obstante o posicionamento adotado, por apertada maioria, na Segunda Seção do STJ, a questão ainda gera acirrado debate, o que parece se comprovar com a afetação do REsp 1.479.864/SP à sistemática dos recursos repetitivos, por decisão de 2015 do Ministro Paulo de Tarso Sanseverino. A decisão tem por escopo que o julgamento do Recurso Especial possa

[...] uniformizar do entendimento sobre as seguintes questões jurídicas: (i) distinção entre responsabilidade

35 Acompanharam a divergência os Ministros Paulo de Tarso Sanseverino, Nancy Andrighi, Ricardo Villas Boas Cuêva e Luis Felipe Salomão. 
contratual e extracontratual em danos causados por acidentes ferroviários; (ii) termo inicial dos juros de mora incidentes na indenização por danos morais nas hipóteses de responsabilidade contratual e extracontratual. ${ }^{36}$

Como se percebe, boa parte dessas questões se relacionam à concepção segundo a qual seria injusto responsabilizar o devedor que não pode cumprir sua obrigação, por desconhecê-la. Ignorando-se a função dos juros no ordenamento jurídico brasileiro - v. item 1, supra, - buscase apoio dogmático com a interpretação enviesada do art. 407 do Código Civil. Cumpre analisar, portanto, a norma objeto da controvérsia.

$\mathrm{O}$ art. 407 reproduz, quase integralmente, o art. 1.064 do Código Civil de 1916. A alteração reduz-se à substituição da expressão "desde que" pela locução "uma vez que". ${ }^{37}$ Não é difícil perceber que a alteração em nada auxiliou na solução da questão, já vetusta, de se "[...] saber se a expressão legal 'desde que' é causal ou, ao invés, temporal”

36 Vale a ressalva, contudo, de que houve voto-vista da Ministra Nancy Andrighi suscitando questão de ordem no sentido de tornar sem efeito a afetação do recurso à Corte Especial e determinar a remessa dos autos à Terceira Turma. Logo após, pediu vista o Ministro João Otávio de Noronha para se manifestar quanto à questão de ordem e, na sessão do dia $1^{\circ}$ de fevereiro de 2017, o Ministro João Otávio de Noronha proferiu voto acolhendo a questão de ordem suscitada pela Ministra Nancy Andrighi, tendo, em seguida, solicitado vista regimental o Ministro Paulo de Tarso Sanseverino. Independentemente do desfecho deste Recurso Especial, certo é que a jurisprudência do STJ tem sinalizado posicionamento no sentido de que "[...] em se tratando de indenização por danos morais decorrentes de obrigação contratual, os juros de mora são devidos a partir da citação" (STJ, AgRg no AREsp 512.919/RJ, $3^{\mathrm{a}}$ T., Rel. Min. Ricardo Villas Bôas Cueva, julg. 24.11.2015; STJ, AgInt no AREsp 730.055/RJ, $3^{\mathrm{a}}$ T., Rel. Min. Moura Ribeiro, julg. 4.10.2016). Desse modo, em casos envolvendo, por exemplo, compensação por dano moral em virtude da morte de familiar em acidente ferroviário, a Corte já decidiu que o termo inicial dos juros de mora é a

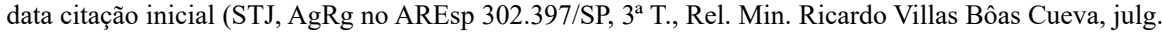
17.12.2015; STJ, REsp 731.527/SP, 4a T., Rel. Min. Aldir Passarinho Junior, julg. 23.6.2009; STJ, REsp 877.195/RJ, $4^{\mathrm{a}}$ T., Rel. Min. Jorge Scartezzini, julg. 28.11.2006). O problema, a rigor, remete à distinção entre responsabilidade contratual e extracontratual, cada vez menos nítida no direito contemporâneo, em especial nas relações de consumo.

37 Enquanto, no CC/1916, estabelecia o artigo 1.064 que: “Ainda que se não alegue prejuízo, é obrigado o devedor aos juros da mora, que se contarão assim às dividas em dinheiro, como às prestações de outra natureza, desde que lhes esteja fixado o valor pecuniário por sentença judicial, arbitramento, ou acordo entre as partes". O artigo 407 do atual Código estatuiu: "Ainda que se não alegue prejuízo, é obrigado o devedor aos juros da mora que se contarão assim às dívidas em dinheiro, como às prestações de outra natureza, uma vez que lhes esteja fixado o valor pecuniário por sentença judicial, arbitramento, ou acordo entre as partes". 
(CARVALHO SANTOS, 1964, p. 307-308). Afinal, os juros de mora deverão ser contados desde a citação, como determina o art. 405 do Código Civil, desde a data da perícia, ou da sentença que estabeleceu o valor líquido correspondente à condenação? Para que se possa interpretar o art. 407, faz-se útil analisar, além do sistema estabelecido pelo Código Civil, a própria origem da parte final do dispositivo. Verifica-se, neste ponto, que no Projeto Bevilaqua o artigo correspondente limitava-se a acentuar que a obrigação de pagar os juros moratórios independeria de alegação de prejuízo por parte do credor, como se percebe da redação do artigo 1.199 do Projeto: "Os juros moratorios, são devidos independentemente da allegação de qualquer prejuízo por parte do credor”. O preceito estava inserido no capítulo $\mathrm{XV}$, destinado à disciplina da taxa aplicável aos juros legais. ${ }^{38} \mathrm{O}$ termo inicial, por sua vez, era matéria dos artigos 1.101-1.103 do Projeto. ${ }^{39}$ No Projeto Revisto, embora se lhe tenha aprimorado a redação, ${ }^{40}$

38 O capítulo XV do Projeto Primitivo ("Dos Juros Legaes") continha apenas três artigos (arts. 1.197, 1.198 e o aludido art. 1.199): "Art. 1.197. A taxa dos juros moratorios, quando não fõr fixada pelas partes, será de seis por cento ao anno"; "Art. 1.198. Será tambem de seis por cento a taxa dos juros devidos por determinação da lei, e a dos produzidos por accórdo das partes, quando estas não fixarem outras"; "Art. 1.199. Os juros moratorios, são devidos independentemente da allegação de qualquer prejuizo por parte do credor".

39 Os artigos estavam inseridos no Livro das Obrigações, Título II ("Dos efeitos das obrigações"), Capítulo II ("Do pagamento"), Seção VI ("Da mora") do Projeto, que se dirigia especificamente à disciplina da constituição em mora, nos seguintes termos: "Art. 1.101. Havendo prazo designado para as obrigações positivas e liquidas, o devedor ficará constituido em móra, desde que o prazo se vencer. Não havendo prazo designado, começa a móra com a primeira citação do réo para o fóro contencioso"; "Art. 1.102. Nas obrigações negativas, o devedor constitue-se em móra, desde o dia em que executar o acto de que se devia abster"; "Art. 1.103. Nas obrigações oriundas de delictos, considera-se o devedor em móra, desde o dia em que prepetrou o delicto".

40 Não foram poucas as críticas lançadas contra a redação do Projeto Bevilaqua. É expressiva a passagem em que o próprio autor comenta a reprimenda dos que alvejaram o trabalho: "Por um lamentavel desvio da critica, versou a discussão muitas vezes entre nós, sobre questões de estylo e grammatica. Fugi o mais possivel de envolver-me nessa contenda bysantina que um só resultado poderia ter: - o de perdermos um tempo consideravel e precioso, si não a opportunidade de obter a passagem do Codigo civil no Congresso. Mas era impossivel ficar quieto, imperturbavel, quando a picareta impiedosa, derrubando a caliça e levantando nuvens de poeira fingia estar solapando a construcção. Desejariam os antagonistas do Projecto vasal-o numa lingua hieratica, impeccavel, que jamais existiu na realidade da vida, que jamais foi falada pelo povo, e que elles suppõem idealmente creada pelos escriptores de sua predilecção" (BEVILAQUA, 1906, p. X). 
o dispositivo permaneceu restrito à afirmação de que os juros de mora são devidos independentemente da alegação de prejuízo por parte do credor. Previa o artigo 1.213 do Projeto Revisto: “Os juros moratorios são devidos independentemente da allegação de prejuízo". A disciplina relativa ao termo inicial, de sua parte, era igualmente tratada no capítulo reservado à mora - particularmente nos artigos 1.109-1.111. ${ }^{41} \mathrm{O}$ Projeto Revisto já apresentava alterações em relação ao Primitivo, sendo interessante notar a nova regulamentação quanto à constituição em mora nas obrigações sem prazo. ${ }^{42}$ Essa foi, contudo, a única modificação relevante na matéria.

No entanto, em parecer de 1901, Amaro Cavalcanti observou criticamente: “O projecto não diz si as suas disposições sobre juros legaes só se applicam aos pagamentos em dinheiro, ou si, também, a qualquer outra prestação, uma vez computada ou convertida em valor monetario" (BRASIL, 1918, p. 433). O eminente jurista, Ministro do Supremo Tribunal Federal entre 1906 e 1914, destacou que o projeto apenas mencionava serem devidos os juros de mora em seu artigo 1.209, que tratava das obrigações de dinheiro. ${ }^{43}$ Levantando a questão, posicionou-se favoravelmente à incidência dos juros independentemente da natureza da prestação: "Acho que elles são devidos em todos os casos de móra, sempre que não haja estipulação contraria a respeito”. Em seguida, conclui seu raciocínio:

41 "Art. 1.109. Nas obrigações positivas e liquidas, o devedor é considerado em móra desde o vencimento do prazo. Não havendo prazo designado, começa a móra desde a interpellação, protesto ou notificação"; "Art. 1.110. Nas obrigações negativas, o devedor fica constituído em móra desde o dia em que executar o acto de que se devia abster"; "Art. 1.111. Nas obrigações provenientes de delicto, considera-se o devedor em móra desde que o perpetrou".

$42 \mathrm{Na} 31^{a}$ Reunião da Comissão Revisora, no dia 26 de julho de 1900, foram incluídos e alterados artigos na Seção VI (Mora). Da ata da reunião, consta que "[...] o Dr. Lacerda, que propôz a emenda, achou conveniente, neste ponto, afastar-se da legislação commercial, mesmo porque a Ordenação não exigia a primeira citação do réo para inicio da móra" (BRASIL, 1917, p. 488).

43 Dispunha o art. 1.209 do Projeto Revisto: "As perdas e damnos, nas obrigações de pagamento em dinheiro, consistem nos juros da móra e custas, sem prejuizo da pena convencional". 
Si a prestação fôr dinheiro, serão contados sobre a importância conhecida da mesma; si fôr causa diversa ou um serviço prestado, sobre o valor pecuniario, que se lhe der por arbitramento ou de outro modo (sentença judicial, accordo das partes, etc.).

Ao seu parecer seguiu-se o de Carlos Augusto de Oliveira Figueiredo, então senador pelo Estado do Rio de Janeiro, e que viria a ser nomeado, em 1911, Ministro do Supremo Tribunal Federal. Nomeado para integrar a comissão especial encarregada de dar parecer sobre as emendas apresentadas ao projeto de Código Civil, ficou responsável pela análise dos artigos do Livro de direito das obrigações (arts. 1.011-1.227). Acerca dos apontamentos de Amaro Cavalcanti, ponderou:

Entra em duvida o Sr. Dr. Amaro Cavalcanti si, dado valor pecuniario a qualquer prestação, tem o credor direito aos juros da móra. A duvida foi levantada em seu espirito pela summaria redação do art. 1.209, que não é supprivel pelo disposto para caso especial pelo art. $1.833 .^{44}$

Concluiu, acompanhando a reflexão proposta, que, “[...] convertida para valor pecuniario qualquer prestação, ella torna-se obrigação de pagamento em dinheiro [...]”, complementando que "[...] parece claro a tal respeito o art. 1.209” (BRASIL, 1918, p. 947).

A partir de tais discussões é que se incorporou ao art. 1.064 do Código Civil de 1916 - correspondente, em substância, ao art. 407 do Código vigente - sua parte final. ${ }^{45}$ Seu objeto, portanto, jamais foi

44 Previa o artigo 1.833 do Projeto Revisto: "Para liquidar a importancia de uma prestação não cumprida, quando tiver valor official no logar da execução, tomar-se-ha o preço médio entre a data do vencimento e a do pagamento, ao qual se addicionarão os juros da móra. Nos outros casos, far-se-ha a liquidação por arbitramento".

45 Como menciona Clovis Bevilaqua (1958, p. 178), os primeiros projetos "limitavam-se a acentuar que os juros moratórios eram devidos, independentemente de alegação de prejuízo por parte do credor. A Câmara é 
a fixação de termo inicial dos juros de mora. A preocupação que deu origem à emenda consistia em esclarecer que a incidência dos juros não estaria restrita às obrigações de dinheiro, estendendo-se também às de outra natureza, o que somente seria possível, à evidência, por meio da fixação de seu valor pecuniário. ${ }^{46}$

Por isso que, justificadamente receoso da confusão que se poderia fazer com o termo inicial dos juros de mora a partir da locução "desde que", Clovis Bevilaqua esclarecia:

A locução 'desde que’ (lhe esteja fixado o valor
pecuniário) não indica o tempo da constituição em
mora, e sim a determinação do que é necessário para
que se possam contar juros das prestações, que não
tem por objeto somas de dinheiro (BRASIL, 1958,
p. 178). ${ }^{47}$

que deu ao artigo a extensão, que êle tem no Código, adotando uma emenda aditiva de Amaro Cavalcanti”. 46 Pontes de Miranda (2012b, p. 85) asseverava a existência de três regras jurídicas decorrentes do aludido artigo, ressaltando, quanto à terceira, não haver relação com a fluência dos juros de mora: "Há três regras jurídicas no art. 1.064: a primeira estabelece o princípio da desnecessidade de dano para eficácia da mora (= mora surte efeitos ainda que nenhum prejuízo tenha havido); a segunda estabelece que, nas dívidas de dinheiro, a mora tem os efeitos de produção de juros desde que ela ocorre, inclusive na espécie do art. 962; a terceira faz depender da sentença, judicial ou arbitral, ou do acôrdo dos interessados a contagem dos juros, nas dívidas em que a prestação não seja de dinheiro, não, porém, a fluência, que é desde a mora". Propunha o autor distinção quanto à contagem e à fluência dos juros moratórios, à luz da jurisprudência da época: "Alguns acórdãos confundem, lamentavelmente, fluência e contagem: $1 .{ }^{a}$ Câmara Cível da Côrte de Apelação do Distrito Federal, 7 de janeiro de 1918 (R. de D., 48, 567; R. J., 11, 159), e 2. ${ }^{\text {a }}$ Câmara, 13 de outubro de 1922, (R. de D., 68, 390; contra, a 15 de julho de 1921, R. de D., 62, 323). [...] A 3. ${ }^{\text {a Câmara }}$ Civil do Tribunal de Justiça de São Paulo, a 5 de junho de 1952 (R. dos T., 203, 194), julgou certo, dizendo que os juros da mora se somam desde a citação inicial, mas sobre o principal, posteriormente determinado na sentença de liquidação. Viu bem a diferença entre fluência e contagem de juros. Apenas deveria ter dito, mais explicitamente: 'desde a citação inicial se de algum momento anterior não fluíam'. Os juros legais contam-se sobre o capital (e sobre os juros devidos, a despeito do Decreto n. 22.626, de 7 de abril de 1933 , art. $4^{\circ}$ ) a partir da citação inicial, se não houve mora anterior. Os juros moratórios correm da mora".

47 Não obstante, respeitável doutrina manteve-se firme na interpretação em sentido contrário. J. M. de Carvalho Santos (1964, p. 307) posicionava-se no sentido de que o artigo veicularia termo inicial para os casos de obrigações ditas "incertas": "[...] claro se nos afigura que exigindo o art. 1.064 que o quantum esteja fixado por um dos modos nele previstos, não é possível deixar de reconhecer que tal exigência é feita justamente para que a contagem dos juros possa ser realizada. Até aí, parece não haver dúvida. Esta surge quando se indaga: Isso, porém, desde quando? Lógica e juridicamente, a solução que se impõe é esta: os juros somente são devidos depois da fixação, mesmo porque não se concebe como os juros possam ser contados e exigidos antes de saber-se a quanto monta o quantum da indenização". Silvio Rodrigues (2002, p. 259-260), de sua parte, afirmava: "Quanto às obrigações de outra natureza, que não as de dinheiro, os juros começam a correr desde que lhes esteja fixado o valor pecuniário por sentença judicial, arbitramento ou acordo entre as partes, pois antes desse momento era impossível o seu curso". 
A análise do debate legislativo a partir do qual se originou a parte final do artigo 407 revela-se extremamente útil à sua interpretação. Evidencia, a mais não poder, a inexistência de qualquer relação entre o escopo da norma e a fixação de termo inicial dos juros de mora. Com efeito, buscou-se unicamente estabelecer que os juros de mora não se limitam às prestações de dinheiro, devendo-se, nas demais prestações, considerar o valor pecuniário como base de cálculo dos juros. ${ }^{48}$ Ademais, considerar que o aludido artigo veicula nova previsão de termo inicial iria de encontro com a sistemática adotada pelo Código, apartando, injustificadamente, o momento da constituição em mora do termo inicial dos juros moratórios. Isso porque a liquidação - por sentença, arbitramento ou acordo - não guarda pertinência com a constituição em mora. ${ }^{49}$

Assim, mesmo nos casos em que a lei previu o termo inicial em momento posterior à citação inicial, o fez em virtude de que somente se poderia falar em mora àquela altura. Pense-se, por exemplo, no caso do artigo 85, § 16, do Código de Processo Civil, que estabelece como termo inicial dos juros de mora incidentes sobre os honorários de sucumbência a data do trânsito em julgado da decisão. O prazo, aqui, refere-se evidentemente à constituição em mora. Afinal, não se cogitaria

48 Como observava Spencer Vampré (1920, p. 191-192), “O art. 1064 não se refere ao tempo desde o qual se devem contar os juros da mora: refere-se tão sómente, ao capital sobre o qual os juros da mora devem ser contados, quando o objecto da divida não fôr dinheiro, mas prestação de outra natureza". Nessa direção, o Professor e Diretor da Faculdade de Direito da Universidade de São Paulo chegou a indicar qual seria a leitura correta da norma: "O artigo 1064 deve, pois, ser lido deste modo: 'Ainda que não se allegue prejuizo, é obrigado o devedor, aos juros da mora, que se contarão assim ás dividas em dinheiro, como ás prestações de outra natureza, fixando-se o valor destas prestações por sentença judicial, arbitramento, ou acordo entre as partes"” (VAMPRÉ, 1920, p. 191-192).

49 Na mesma direção, Judith Martins-Costa (2003, p. 407) afirma que "[...] não há como confundir-se o 'desde que' (alusivo ao fato de estar fixado o valor pecuniário da prestação) com o tempo da constituição em mora. Fica claro que os juros de mora se contam, uma vez que esteja fixado o valor das prestações não pecuniárias, observando-se, consoante as particulares regras de constituição em mora (mora ex re ou mora ex persona), o dies a quo correspondente". Cf., na mesma linha, (FERREIRA DA SILVA, 2007, p. 230-231). 
de mora na obrigação de pagamento de honorários de sucumbência em momento anterior à própria sucumbência.

A constituição em mora tem como função precisamente assinalar o momento a partir do qual incidem os efeitos da mora, dentre os quais sobrelevam os juros. ${ }^{50}$ Como antes anotado, a imposição de pagamento dos juros de mora repousa na presunção de que a privação da prestação devida gera prejuízo ao credor, assim como pode representar, para o devedor, lucro ilícito, na medida em que proveniente da indevida disponibilidade de uma riqueza. Não há, portanto, qualquer arbitrariedade na opção legislativa de se contarem os juros em momento anterior à liquidação da obrigação. ${ }^{51}$

\section{CONCLUSÃO}

A complexidade na sistematização da disciplina dos juros moratórios no direito brasileiro justifica-se, em larga medida, pela pouca

50 Caio Mário da Silva Pereira (2016, p. 294-295) leciona que, constituído o devedor em mora, "[...] duas são as ordens de seus efeitos: a responsabilidade pelas perdas e danos e a perpetuação da obrigação". Esclarece que o devedor fica obrigado "[...] a indenizar o credor pelo dano que o atraso the causar, seja mediante o pagamento dos juros moratórios legais ou convencionais, seja ressarcindo o que o retardo tiver gerado [...]. Outro efeito da mora debendi é a denominada perpetuatio obligationis, em virtude de que responde o devedor moroso pela impossibilidade da prestação, ainda que tal impossibilidade decorra de caso fortuito ou de força maior" (PEREIRA, 2016, p. 294-295).

51 "O fato de a prestação postulada ser ilíquida apenas posterga a base de cálculo sem qualquer interferência no termo legal da contagem dos juros moratórios. Outrossim, convém ponderar que a manutenção da solução da contagem dos juros de mora após o trânsito em julgado premia o devedor que mantém o capital do credor sem qualquer remuneração" (SCAVONE JUNIOR, 2014, p. 138). Na jurisprudência, igualmente, verifica-se orientação voltada à incidência dos juros, mesmo nos casos de obrigação ilíquida, desde a citação inicial, se não houver constituição em mora em momento anterior. Ao propósito, confira-se a Súmula 163 do Supremo Tribunal Federal: "Salvo contra a Fazenda Pública, sendo a obrigação ilíquida, contam-se os juros moratórios desde a citação inicial para a ação". Expressa o mesmo posicionamento a Súmula 204 do STJ: "Os juros de mora nas ações relativas a benefícios previdenciários incidem a partir da citação válida". O Superior Tribunal de Justiça, inclusive, firmou tese, em sede de recurso repetitivo, no sentido de que "[...] os juros de mora incidem a partir da citação do devedor no processo de conhecimento da Ação Civil Pública quando esta se fundar em responsabilidade contratual, cujo inadimplemento já produza a mora, salvo a configuração da mora em momento anterior". Afirmou-se, no caso, que "[...] a jurisprudência desta Corte, embora não tratando de pretensão coletiva, não vê obstáculo à incidência de juros moratórios em período anterior à liquidação do crédito" (STJ, REsp 1.361.800/SP, Corte Especial, Rel. p/ Acórdão Min. Sidnei Beneti, julg. 21.5.2014). 
atenção dispensada ao exame da função dos juros. Acentua-se o problema em razão da disputa histórica, por motivações religiosas e políticas, em torno da legitimidade da regulamentação dos juros, já comparados até mesmo ao assassinato. ${ }^{52}$ Nos sistemas hodiernos, contudo, os juros não apenas são admitidos, como desempenham papel fundamental na economia global. Assumem, outrossim, relevante função no direito das obrigações, integrando, como efeito do inadimplemento, a prestação devida pelo devedor que descumpre o dever que lhe incumbia.

Subsistem, por outro lado, algumas polêmicas especialmente quanto à taxa e ao termo inicial dos juros moratórios. No que diz respeito a este último aspecto, o ordenamento jurídico brasileiro reservou disciplina específica, composta pelos artigos que regulam a constituição em mora nas diversas modalidades de obrigações, ${ }^{53}$ cujo conteúdo é ratificado por outras normas do sistema, como os artigos 405 e 407 do Código Civil e o artigo 240, caput, do Código de Processo Civil. Verifica-se, porém, certa dificuldade na aplicação dos aludidos preceitos, sobretudo diante de obrigações ilíquidas, nas quais há quem se mostre refratário à responsabilização do devedor com base em obrigação por este desconhecida, porquanto ausente predefinição do objeto - os juros de mora incidentes sobre o valor devido a título de compensação por dano moral parecem ilustrar bem a hipótese. Seguindo tal linha argumentativa, sustenta-se, em alguns casos, que os juros de mora deveriam correr somente a partir do momento em que estabelecido o valor líquido correspondente à condenação, o que se poderia extrair, à primeira leitura, da parte final do artigo 407 do Código Civil, que prevê que os juros de mora "[...] se contarão assim às dívidas em dinheiro, como às prestações

52 Manoel Ignacio Carvalho de Mendonça (1911, p. 90) observa que Cicero “[...] comparava o juro ao assassinato. Quid fenerari. Quid ominem occidere?".

53 Trata-se dos artigos 390, 397, caput e parágrafo único, e 398 do Código Civil. 
de outra natureza, uma vez que lhes esteja fixado o valor pecuniário por sentença judicial, arbitramento, ou acordo entre as partes" (BRASIL, 2002, grifou-se).

Esta proposta interpretativa, como se procurou demonstrar, parte de dois pressupostos equivocados: o primeiro quanto à função dos juros no ordenamento jurídico brasileiro e o segundo no que tange à interpretação do artigo 407 do Código Civil. Os juros moratórios encontram sua ratio na compensação da vítima do descumprimento pela indevida privação do capital de que poderia dispor em virtude da lesão suportada - e na sanção do inadimplente - por conta da vedação ao enriquecimento sem causa.

De outra parte, a compreensão do artigo 407 do Código Civil como supedâneo para nova hipótese de termo inicial dos juros moratórios, a partir da expressão "uma vez que", revela-se contrária à interpretação histórico-sistemática da norma, que, vinculada ao aspecto quantitativo dos juros ${ }^{54}$ - notadamente quanto à sua base de cálculo -, não guarda pertinência com o termo inicial, conclusão que se mostra coerente com a origem legislativa do dispositivo.

\section{REFERÊNCIAS}

ALMEIDA, Lacerda de. Dos effeitos das obrigações. Rio de Janeiro: Livraria Editora Freitas Bastos, 1934.

\section{ALVIM, Agostinho. Da inexecução das obrigações e suas consequências. São Paulo: Saraiva, 1972.}

\section{AZEVEDO, Álvaro Villaça. Teoria geral das obrigações e}

54 O próprio Capítulo em que se insere a norma (Capítulo IV - Dos Juros Legais) tem por escopo o aspecto quantitativo dos juros, destinando-se o artigo anterior (art. 405) à determinação taxa de juros aplicável. 
responsabilidade civil. São Paulo: Atlas, 2011.

BARASSI, Ludovico. La teoria generale delle obbligazioni. Milano: Giuffrè Editore, 1946. v. III.

BEVILAQUA, Clovis. Em defeza do projecto de código civil brazileiro. Rio de Janeiro: Livraria Francisco Alves, 1906.

. Direito das coisas. 5. ed. atual. por José de Aguiar Dias. Rio de Janeiro: Forense, 1958. v. I.

BRASIL. Código Civil brasileiro: trabalhos relativos à sua elaboração. Rio de Janeiro: Imprensa Nacional, 1917. v. I.

. Código Civil brasileiro: trabalhos relativos à sua elaboração. Rio de Janeiro: Imprensa Nacional, 1918. v. 2.

. Código Civil dos Estados Unidos do Brasil comentado. Rio de Janeiro: Editora Paulo de Azevedo Ltda., 1958. v. IV.

. Lei n. ${ }^{\circ} 3.071$, de 01 de janeiro de 1916. Código Civil dos Estados Unidos do Brasil. Disponível em: < http://www.planalto.gov. br/ccivil_03/leis/L3071.htm>. Acesso em: 18 mar. 2017.

. Lei n. ${ }^{\circ} 10.406$, de 10 de janeiro de 2002. Código Civil.

Disponível em: $<$ http://www.planalto.gov.br/ccivil_03/leis/2002/ 110406.htm>. Acesso em: 18 mar. 2017.

. Lei n. ${ }^{\circ} 13.105$, de 16 de março de 2015. Código de Processo Civil. Disponível em: < http://www.planalto.gov.br/ ccivil_03/_Ato2015-2018/2015/Lei/L13105.htm>. Acesso em: 18 mar. 2017.

. Superior Tribunal de Justiça, REsp 877.195/RJ, $4^{\mathrm{a}}$ T., Rel. 
Min. Jorge Scartezzini, julg. 28.11.2006.

. Superior Tribunal de Justiça, EREsp 727.842/SP, Corte

Especial, Rel. Min. Teori Albino Zavascki, julg. 8.9.2008.

. Superior Tribunal de Justiça, REsp 1.061.530/RS, $2^{\mathrm{a}}$ S., Rel. Min. Nancy Andrighi, julg. 22.10.2008.

. Superior Tribunal de Justiça, REsp 731.527/SP, $4^{\mathrm{a}}$ T., Rel. Min. Aldir Passarinho Junior, julg. 23.6.2009.

. Superior Tribunal de Justiça, REsp 903.258/RS, $4^{\mathrm{a}}$ T., Rel. Min. Maria Isabel Gallotti, julg. 21.6.2011.

. Superior Tribunal de Justiça, REsp 888.751/BA, $4^{\mathrm{a}} \mathrm{T}$., Rel. Min. Raul Araújo, julg. 25.10.2011.

. Superior Tribunal de Justiça, REsp 1.201.340/DF, $4^{\mathrm{a}} \mathrm{T}$., Rel. Min. Maria Isabel Gallotti, julg. 3.11.2011.

. Superior Tribunal de Justiça, REsp 1.132.866/SP, 2a S., Rel. Min. Maria Isabel Gallotti, Rel. p/ Acórdão Min. Sidnei Beneti, julg. 23.11.2011.

. Superior Tribunal de Justiça, REsp 1.114.398/PR, $2^{\mathrm{a}} \mathrm{S}$., Rel. Min. Sidnei Beneti, julg. 8.2.2012.

. Superior Tribunal de Justiça, EDcl no REsp 1.025.298/ RS, 2 ${ }^{a}$ S., Rel. p/ Acórdão Min. Luis Felipe Salomão, julg. 28.11.2012.

. Superior Tribunal de Justiça, EREsp 903.258/RS, Corte Especial, Rel. Min. Ari Pargendler, julg. 15.5.2013.

. Superior Tribunal de Justiça, REsp 1.361.800/SP, Corte 
Especial, Rel. p/ Acórdão Min. Sidnei Beneti, julg. 21.5.2014.

. Superior Tribunal de Justiça, AgRg no AREsp 401.543/ RJ, 4 $4^{\mathrm{a}}$ T., Rel. Min. Luis Felipe Salomão, julg. 24.3.2015.

. Superior Tribunal de Justiça, REsp 1.479.864/SP, Rel. Min. Paulo de Tarso Sanseverino, decisão de afetação em 23.4.2015.

. Superior Tribunal de Justiça, REsp 1.556.834/SP, Rel. Min. Luis Felipe Salomão, decisão de afetação em 16.11.2015.

. Superior Tribunal de Justiça, AgRg no AREsp 512.919/ RJ, $3^{\mathrm{a}}$ T., Rel. Min. Ricardo Villas Bôas Cueva, julg. 24.11.2015.

. Superior Tribunal de Justiça, AgRg no AREsp 302.397/ SP, $3^{\text {a }}$ T., Rel. Min. Ricardo Villas Bôas Cueva, julg. 17.12.2015.

. Superior Tribunal de Justiça, REsp 1.270.983/SP, $4^{\mathrm{a}}$ T., Rel. Min. Luis Felipe Salomão, julg. 8.3.2016.

. Superior Tribunal de Justiça, AgRg no REsp 1.459.006/

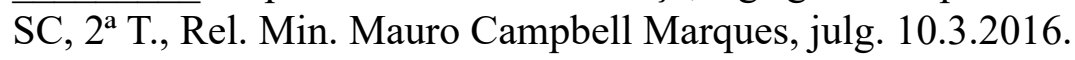

. Superior Tribunal de Justiça, AgInt no AREsp 730.055/ RJ, $3^{\text {a }}$ T., Rel. Min. Moura Ribeiro, julg. 4.10.2016.

CÂMARA LEAL, Antônio Luis da. Codigo do processo civil e commercial do Estado de São Paulo commentado. São Paulo: Livraria Academica, 1930. v. II.

CAMPINHO, Sérgio. Sobre os juros no Código Civil de 2002. In: Revista de Direito Empresarial, Curitiba, n. 3, jan./jun. 2005.

CARVALHO DE MENDONÇA, Manoel Ignacio. Doutrina e prática 
das obrigações ou tratado geral dos direitos de crédito. Rio de Janeiro: Editora Francisco Alves e Cia, 1911. v. II.

. Doutrina e prática das obrigações ou tratado geral dos direitos de crédito. Rio de Janeiro: Editora Francisco Alves e Cia, 1911. v. II.

CARVALHO DE MENDONÇA, José Xavier. Tratado de direito comercial brasileiro. Rio de Janeiro: Livraria Freitas Bastos S.A., 1960. v. VI.

CARVALHO SANTOS, J. M. de. Código civil brasileiro interpretado. Rio de Janeiro: Livraria Freitas Bastos S.A., 1963. v. XII.

. Código civil brasileiro interpretado. Rio de Janeiro:

Livraria Freitas Bastos S.A., 1964. v. XIV.

DIDIER JR., Fredie. Curso de direito processual civil. Salvador: Jus Podivm, 2015. v. 1.

FACHIN, Luiz Edson. Responsabilidade civil contemporânea no Brasil: notas para uma aproximação. In: Revista jurídica, v. 58, Porto Alegre: Notadez, 2010.

FERRAZ, José Eduardo Coelho Branco Junqueira. In: TEPEDINO, Gustavo (Org.). Obrigações: estudos na perspectiva civilconstitucional. Rio de Janeiro: Renovar, 2005.

FERREIRA DA SILVA, Jorge Cesa. Inadimplemento das obrigações. São Paulo: Revista dos Tribunais, 2007.

GOMES, Orlando. Transformações gerais do direito das obrigações. São Paulo: Revista dos Tribunais, 1980. 
. Tendências modernas na teoria da responsabilidade civil. In: DI FRANCESCO, José Roberto Pacheco (Org.). Estudos em homenagem ao Professor Silvio Rodrigues, São Paulo: Saraiva, 1989.

. Obrigações. 18. ed. Rio de Janeiro: Forense, 2016.

ICC INTERNATIONAL COURT OF ARBITRATION. Final Award, ICC Case n. 16369, 2011. In: VAN DEN BERG, Albert Jan (Ed.). Yearbook Commercial Arbitration 2014. Kluwer Law International, 2014. v. XXXIX, p. 169-215.

KONDER, Carlos Nelson. Enriquecimento sem causa e pagamento indevido. In: TEPEDINO, Gustavo (Coord.). Obrigações: estudos na perspectiva civil-constitucional. Rio de Janeiro: Renovar, 2005.

LIBERTINI, Mario. Interessi. In: Enciclopedia del Diritto. Milano: Giuffrè Editore, 1972. v. XXII.

LINS, Thiago. O lucro da intervenção e o direito à imagem. Rio de Janeiro: Lumen Juris, 2016.

MAGALHÃES, José Carlos de. A cláusula arbitral nos contratos internacionais. In: WALD, Arnoldo (Org.). Arbitragem e mediação: elementos da arbitragem e medidas de urgência, São Paulo: Revista dos Tribunais, 2014.

MARTINS-COSTA, Judith. Comentários ao novo código civil. Rio de Janeiro: Forense, 2003. v. V. t. II.

MATTIETTO, Leonardo. Os juros legais e o art. 406 do Código Civil. Revista Trimestral de Direito Civil - RTDC, v. 15, 2003. 
MONTEIRO, Washington de Barros. Curso de direito civil. São Paulo: Saraiva, 2007. v. 4.

PEREIRA, Caio Mário da Silva. Instituições de direito civil. 28. ed. Rio de Janeiro: Forense, 2016. v. II.

. Instituições de direito civil. 18. ed. Rio de Janeiro:

Forense, 2014. v. III.

PONTES DE MIRANDA, Francisco Cavalcanti. Tratado de direito privado. São Paulo: Revista dos Tribunais, 2012a. t. XXII.

. Tratado de direito privado. São Paulo: Revista dos Tribunais, 2012b. t. XXIV.

RODRIGUES, Silvio. Direito civil. São Paulo: Saraiva, 2002. v. 2.

SCAVONE JUNIOR, Luiz Antonio. Juros no direito brasileiro. Rio de Janeiro: Forense, 2014.

SCHREIBER, Anderson. Novas tendências da responsabilidade civil brasileira. In: Direito Civil e Constituição. São Paulo: Atlas, 2013.

TEPEDINO, Gustavo; SCHREIBER, Anderson. Código civil comentado. São Paulo: Atlas, 2008. v. IV.

. Estipulação contratual de opção unilateral de venda: controvérsias envolvendo o direito ao put. In: TEPEDINO, Gustavo (Org.). Soluções Práticas de Direito: pareceres. São Paulo: Revista dos Tribunais, 2012, v. II.

- Atividade interpretativa e o papel da doutrina e da jurisprudência. Revista Brasileira de Direito Civil - RBDCivil, v. 2, p. 6-8, out.-dez./2014. 
TERRA, Aline de Miranda Valverde. Disgorgement of profits in brazilian law. In: E. Hondius, A. Janssen (Org.). Disgorgement of Profits, Ius Comparatum - Global Studies in Comparative Law. New York City: Springer International Publishing, 2015. v. 8.

VAMPRÉ, Spencer. Juros Moratórios. Revista dos Tribunais, São Paulo, v. 35, jul./1920.

WALD, Arnoldo. Aplicação da teoria das dívidas de valor às pensões decorrentes de atos ilícitos. Rio de Janeiro: Editora Nacional de Direito Ltda., 1959.

Como citar: TEPEDINO, Gustavo; VIÉGAS, Francisco. Notas sobre o termo inicial dos juros de mora e o artigo 407 do Código Civil. Scientia Iuris, Londrina, v. 21, n. 1, p.55-86, mar. 2017. DOI: 10.5433/2178-8189.2017v21n1p55. ISSN: 2178-8189.

Recebido em: 05/12/2016

Aprovado em: 10/03/2017 